\title{
Storage Period Affects Weight Loss of Japanese Quail Eggs
}

http://dx.doi.org/10.1590/1806-9061-2015-0178

"Author(s)
Roriz BC'
Sgavioli S"
Garcia RG'
Nääs IA'
Domingues CHF'
Caldara FR'
Rombola LG"I
Ayla CM'
Bernnecke K"

' Federal University of Grande Dourados -
College of Agricultural Sciences, 79.804-
970, Dourados-MS, Brazil.
" Brazil University, 13.690-970, Descalvado-
SP, Brazil.
"I Animal Scientist, 13.690-000, Descalvado-
-SP, Brazil.

\section{Mail Address}

Corresponding author e-mail address Sarah Sgavioli

Brazil University, Av. Hilário da Silva Passos, 950, Descalvado, SP, Brazil.

Zip code: 13690-790

Tel: $\quad$ +55 $1698116-4120$

Email: sarahsgavioli@yahoo.com.br

\section{nKeywords}

Embryo, hatchability, incubation, laying, temperature.

\section{ABSTRACT}

Long storage periods may increase embryo mortality. The objective of this study was to evaluate the effects of storage period on the weight loss, eggshell surface temperature, hatchability, and embryonic mortality of Japanese quail eggs. Two hundred fertile eggs were collected from a flock of 30-week-old Japanese quails (Coturnix coturnix japonica). The eggs were collected for 10 consecutive days after lay, and immediately incubated. A completely randomized experimental design with 10 treatments, corresponding to the number of days eggs were stored between egg collection and setting, with 20 replicates each, was applied. Egg weight loss increased with storage period duration, starting on day $6(2.1 \%$, on average) and reached $3.26 \%$, on average, in eggs stored for 10 days. The highest hatchability ( $p>0.05)$ was obtained in eggs stored for two days, which also lost the least weight (1.20\%). Storage period did not influence eggshell surface temperature $(p>0.05)$ during incubation, but higher temperatures $(p<0.05)$ were measured on days 10 and 15 of incubation compared with day 5 . Eggs stored for ten days presented the highest weight loss, and therefore, a storage period of up to five days is recommended to maintain the quality of incubated Japanese quail eggs. Furthermore, egg surface temperature increases during the second half of the incubation period as a result of increasing embryonic metabolic rate.

\section{INTRODUCTION}

Egg storage is essential in modern poultry production to supply the constant market demands and hatchery production flow (Christensen, 2001). Egg storage is a routine step in commercial hatcheries. It aims at reducing the cost of egg transportation to the hatchery, obtaining a sufficient number of eggs to fully load the setters, and synchronizing hatching (Fasenko et al., 2001a).

The success of incubation requires optimal management practices that take into account environmental conditions, biological factors (stress level, electrolyte balance, thermoregulation, and post-hatch livability), and physical factors (temperature, humidity, and egg turning) (Sarcinelli, 2012). Temperature and humidity are the main factors that affect embryo livability during incubation (Boleli, 2013).

The storage period can influence egg quality. Long storage periods may increase embryonic mortality by inducing cell death via necrosis and apoptosis, and delay embryonic growth recovery, even when optimal incubation conditions are provided, resulting in slow embryonic growth rates (Fasenko, 2007). Embryonic mortality rates are highest during the first three days of incubation and pre-hatch phase, and are usually due to embryo malformation (Murakami \& Ariki, 1998). 
Fertile Japanese quail eggs producers often do not have adequate equipment and technology that allow minimal egg quality losses during storage (Pedroso et al., 2006). Considering the high demand of eggs and the factors that directly influence incubation, the gradual effect of storage on egg quality should be taken into account.

Therefore, the objective of this study was to evaluate the effects of storage period on weight loss, eggshell surface temperature during incubation, hatchability, and embryonic mortality of eggs laid by 30 -week-old Japanese quails.

\section{MATERIALS AND METHODS}

The experiment was conducted in the experimental hatchery of the School of Agricultural Sciences, Federal University of Grande Dourados, state of Mato Grosso do Sul, Brazil. Two hundred fertile eggs were collected from a flock of 30-week-old Japanese quails (Coturnix coturnix japonica) for 10 consecutive days before incubation.

Immediately after collection, eggs were individually weighed, labeled, packed in cardboard boxes, and stored in a room at $23^{\circ} \mathrm{C}$ and $60 \%$ humidity. Egg weight loss during storage was determined as weight at the beginning of incubation minus weight at the time of collection. Eggs were individually placed in tulle bags and randomly distributed in a setter at $37.5^{\circ} \mathrm{C}$ average temperature and $65 \%$ relative humidity. The eggs were kept in a horizontal position and automatically turned at a $45^{\circ}$ angle to either side every hour. On day 16 of incubation, the eggs were transferred to a hatcher at $37.5^{\circ}$ and $60 \%$ humidity.

\section{Egg surface temperature}

Egg surface temperature in the setter was measured using infrared thermography (IR Text Software Testo 880 V1.4, 2009®) with $\pm 0.1^{\circ} \mathrm{C}$ accuracy and at 7.5 to $13 \mu \mathrm{m}$ spectra on incubation days 510 , and 15 , recording three thermographic images per treatment. For image analyses, a point was marked on each egg, using 0.95 emissivity ratio. The software program used to translate the spectrum of color temperature was IRSoft.

\section{Relative weight, hatchability, and embry- onic mortality}

The chicks were weighed at hatch. Hatchability was calculated as the number of hatched chicks relative to the number of fertile eggs (determined by embryo diagnosis) set. Unhatched eggs were submitted to embryo diagnosis and classified as infertile (INF), early mortality (0-7 days; EM), intermediate mortality (8-14 days; IM), and late mortality (15-21 days; LM).

\section{Experimental design and statistical analyses}

A completely randomized experimental design (CRED) with 10 treatments, corresponding to the number of days were stored between egg collection and setting (days of storage: $1,2,3,4,5,6,7,8,9$, and 10), with 20 replicates each, was applied. Eggshell surface temperature was analyzed according to a CRED in $10 \times 3$ factorial arrangement (10 days of storage vs. 3 days of incubation). Data were submitted to analysis of variance, and in case of significance $(p<0.05)$, means were compared by Tukey's test using SAS statistical package (SAS, 2002). Hatchability and embryonic mortality data were submitted to the frequency test, and means were compared by the Chi-square test at $5 \%$ probability level.

\section{RESULTS}

Storage duration influenced egg weight loss $(p<0.05$; Table 1). Egg weight loss increased with storage period duration, starting on day $6(2.1 \%$, on average $)$ and reaching $3.26 \%$, on average, in eggs stored for 10 days. Hatchability rates ranged between 40-85\%. The highest hatchability ( $p>0.05)$ was obtained in eggs stored for two days, which weight loss was low $(1.20 \%)$ (Table 2$)$. Although not statistically significant, it was observed that early embryonic mortality was higher ( $p>0.05$ ) when eggs lost more weight during storage, particularly in eggs stored for eight days.

Table 1 - Parameters of incubated quail eggs stored during 10 days.

\begin{tabular}{ccccc}
\hline $\begin{array}{c}\text { Storage period } \\
\text { (days) }\end{array}$ & $\begin{array}{c}\text { Initial } \\
\text { weight } \\
(\mathrm{g})\end{array}$ & $\begin{array}{c}\text { Final } \\
\text { weight } \\
(\mathrm{g})\end{array}$ & $\begin{array}{c}\text { Weight } \\
\text { loss } \\
(\%)\end{array}$ & $\begin{array}{c}\text { Relative } \\
\text { weight } \\
(\%)\end{array}$ \\
\hline 1 & 9.95 & 9.85 & $0.97 \mathrm{c}$ & 68.21 \\
2 & 9.91 & 9.79 & $1.20 \mathrm{c}$ & 69.92 \\
3 & 9.88 & 9.74 & $1.45 \mathrm{bc}$ & 68.18 \\
4 & 10.19 & 10.03 & $1.53 \mathrm{bc}$ & 68.33 \\
5 & 9.89 & 9.70 & $1.99 \mathrm{~b}$ & 66.55 \\
6 & 9.94 & 9.59 & $2.44 \mathrm{a}$ & 66.81 \\
7 & 10.01 & 9.54 & $2.80 \mathrm{a}$ & 68.27 \\
8 & 9.90 & 9.49 & $3.03 \mathrm{a}$ & 69.10 \\
9 & 10.01 & 9.69 & $2.76 \mathrm{a}$ & 69.40 \\
10 & 10.07 & 9.74 & $3.26 \mathrm{a}$ & 68.43 \\
\hline$P$ & 0.4840 & 0.0864 & $<0.0001$ & 0.3699 \\
$E P$ & 0.103 & 0.129 & 0.290 & 0.927 \\
\hline
\end{tabular}

P: probabilidade. EP: erro padrão. a-b means followed by different letters differ significantly. 
Table 2 - Embrionary hatching and mortality of quail fertile eggs during different periods of storage.

\begin{tabular}{lccccc}
\hline \multirow{2}{*}{ Storage period (days) } & Hatching & \multicolumn{3}{c}{ Embryo mortality (\%) } \\
\cline { 3 - 6 } & $(\%)$ & INC & \multicolumn{2}{c}{ INT } & \multicolumn{2}{c}{ TT } \\
\hline 1 & 50.00 & 12.50 & 25.00 & 12.50 & 50.00 \\
2 & 84.62 & 0.00 & 7.69 & 7.69 & 15.38 \\
3 & 70.60 & 11.75 & 0.00 & 17.65 & 29.40 \\
4 & 79.17 & 4.17 & 8.33 & 8.33 & 20.83 \\
\hline 5 & 70.59 & 23.53 & 5.88 & 0.00 & 29.41 \\
6 & 70.00 & 15.00 & 10.00 & 5.00 & 30.00 \\
7 & 65.22 & 13.04 & 8.70 & 13.04 & 37.78 \\
8 & 50.00 & 35.00 & 10.00 & 5.00 & 50.00 \\
9 & 40.00 & 15.00 & 25.00 & 20.00 & 40.00 \\
\hline P-QQ & 52.17 & 21.74 & 8.70 & 17.39 \\
\hline EP & 0.2424 & 0.2673 & 0.2424 & 0.2424 & 47.83 \\
\hline
\end{tabular}

INC:initial. INT:intermediate.P-QQ:probability using Chi-Square test. EP:standard error.

Egg surface temperature was not influenced ( $p>0.05$ ) by storage period (Table 3 ). However, egg surface temperature was lower on day 5 of incubation $(p<0.05)$ compared with days 10 and 15 .

Table 3 - Fertile quail egg mean surface temperature at the 5th, 10th, and 15th day of incubation.

\begin{tabular}{ll}
\hline Storage period (PA) & Average \\
\hline 1 & 34.72 \\
\hline 2 & 34.85 \\
\hline 3 & 34.81 \\
\hline 4 & 34.67 \\
\hline 5 & 34.02 \\
\hline 6 & 34.92 \\
\hline 7 & 34.84 \\
\hline 8 & 34.84 \\
\hline 9 & 34.96 \\
\hline 10 & 35.03 \\
\hline Days of incubation (DI) & \\
\hline 5 & $34.20 \mathrm{~b}$ \\
\hline 10 & $35.15 \mathrm{a}$ \\
\hline 15 & $35.15 \mathrm{a}$ \\
\hline Probability & \\
\hline DA & 0.207 \\
DI & 0.000 \\
DA x DI & 0.799 \\
\hline EP & 0.50 \\
\hline
\end{tabular}

$a-b$ means followed by different letters differ significantly

\section{DISCUSSION}

The aim of this study was to evaluate the influence of storage duration on egg weight loss, hatchability, embryo mortality, and surface temperature of Japanese quail eggs stored for $1-10$ days at $23^{\circ} \mathrm{C}$ before incubation.
Egg weight loss increased up to $2.1 \%$ as storage period increased. Eggs lost, on average, $0.2 \%$ of their weight per day, and up to $0.5 \%$ when stored for 10 days. Pedroso et al. (2006) also reported $0.2 \%$ average weight loss per day of storage at room temperature in Japanese quail eggs, and losses greater than $0.6 \%$ on 3 and 6 days of storage. Moura et al. (2008) observed higher weight loss in Japanese quail eggs stored at room temperature compared with those stored under refrigeration, and increasing egg weight loss with storage period, which reached $2.67 \%$ in eggs stored for 10 days.

Egg weight loss is the result of the release of water caused by albumen breakdown, and its subsequent passage through the eggshell. Albumen quality is influenced by storage time and conditions, as well as breeder age (Brake et al., 1997; Tona et al., 2003). High egg weight losses can cause dehydration and high early embryonic mortality, whereas insufficient losses result in late embryo mortality, because the embryos are not able to inflate their lungs immediately before hatch due to the presence of excessive water in the egg (Sarcinelli, 2012).

The higher egg weight loss from the fifth day of storage may have caused worse hatchability. Although the results were not significant, eggs stored for more than five days presented $55.49 \%$ hatchability, while for eggs stored for two days hatchability was $84.62 \%$ on average.

According to Brake et al. (1997), external factors that influence the successful hatching of fertile eggs also affect albumen characteristics. Eggs lose weight due to dehydration, which also affects albumen quality. 
Albumen quality losses are caused by egg $\mathrm{pH}$ reduction and high temperature and humidity fluctuations in the setter of the incubator, which, combined with the effects of storage duration, result in egg weight loss.

Fasenko et al. (2001a) observed $87.5 \%$ and $70.5 \%$ hatchability in chicken eggs stored at $11.5^{\circ} \mathrm{C}$ for four and 14 days, respectively, and $70.42 \%$ and $65.6 \%$ hatchability in turkeys eggs stored at $17.4^{\circ} \mathrm{C}$ for the same periods (Fasenko et al., 2001b). Seker et al. (2005) stored Japanese quail eggs between 9 to 12 ${ }^{\circ} \mathrm{C}$ and $70-75 \%$ relative humidity for 15 days and obtained 90.00, 88.74, 67.96, 72.45, and 50.31\% in eggs stored up to three days, 4-6 days, 7-9 days, 10-12 days, and 13-15 days, respectively. Moraes et al. (2009) determined 90\% hatchability in meat-type Japanese quail eggs stored for four days and $75 \%$ in those stored for 14 days.

Eggshell surface temperature is used as an indicator of in-ovo metabolic heat production (Lourens et al., 2007). According to Murakami \& Araki (1998), Japanese quail eggs should be set at $37.5^{\circ} \mathrm{C}$ and $60 \%$ relative humidity. During the first ten days of incubation, corresponding to the first half of incubation, embryonic metabolic rate is low, and the egg needs to absorb heat from the setter environment, whereas during the fetal stage, metabolic heat production increases and consequently, eggshell surface temperature (French, 1997).

In the present study, higher eggshell temperatures were recorded on days 10 and 15 of incubation, independently of the storage time, indicating that embryonic metabolic rate was not affected by storage period. These results are consistent with the reported by Sgavioli et al. (2015), who observed higher eggshell surface temperature in the second half of the incubation period of broiler eggs submitted or not heat stress during incubation and injected or not with vitamin C.

Eggshell surface temperature measurements during incubation indicated an uneven distribution of temperature inside the setter, which was lower than that recommended. This suggests that the use of the thermographic camera to measure eggshell temperature may not have been efficient, because of the need to open the setter to make the measurements. Therefore, it is recommended to place thermocouples on the eggs and/or a fixed infrared thermometer in the setter.

\section{CONCLUSIONS}

Eggs stored for ten days presented the highest weight loss, and therefore, a storage period of up to five days is recommended to maintain the quality of incubated Japanese quail eggs. Furthermore, egg surface temperature increases during the second half of the incubation period as a result of increasing embryonic metabolic rate.

\section{REFERENCES}

Boleli IC. Estresse, mortalidade e malformações embrionárias. In: Macari M, Gonzáles E, Patrício IS, Nääs IA, Martins PC. Manejo da incubação. Campinas: Fundação APINCO de Ciência e Tecnologia Avícolas; 2013. p. 177-193.

Brake J, Walsh TJ, Benton Jr CE, Petitte JN, Meijerhof R, Pen Alva G. Egg handling and storage. Brazilian Journal of Poultry Science 1997;76:144151.

Christensen VL, Wineland MJ, Fasenko GM, Donaldson WE. Egg storage effects on plasma glucose and supply and demand tissue glycogen concentrations of broiler embryos. Poultry Science 2001;80:17291735 .

Fasenko GM, Robinson FE, Whelan Al, Kremeniuk KM, Walker JA Prestorage incubation of long-term stored broiler breeder eggs. 1. Effects on hatchability. Poultry Science 2001a;80:1406-1411.

Fasenko GM, Christensen VL, Wineland MJ, Petitte JN. Examining the effects of prestorage incubation on turkey breeder eggs on embryonic development and hatchability of eggs stored for four or fourteen days. Poultry Science 2001b;80:132-138.

Fasenko GM. Egg storage and the embryo. Poultry Science 2007;86:10201024

French NA. Modeling incubator temperature: The effects of incubator design, embryonic development, and egg size. Poultry Science 1997;76:24-133.

Lourens A, Brand VH, Heetkamp MJW, Meijerhof R, Kemp B. Effects of eggshell temperature and oxygen concentration on embryo growth and metabolism during incubation. Poultry Science 2007;86:21942199.

Moraes TGV, Romao JM, Cardoso TG. Parâmetros da incubação e componentes dos ovos de codornas japonesas para corte (Coturnix coturnix japonica) submetidos à estocagem em baixas temperaturas (7,5 $\left.\pm 1^{\circ} \mathrm{C}\right)$. Ciências Agrárias 2009;30(1):233-242.

Moura AMA, Oliveira NTE, Thiebau TJTL, Melo TV. Efeito da temperatura de estocagem e do tipo de embalagem sobre a qualidade interna de ovos de codornas japonesas (Coturnix japonica) Ciência e Agrotecnologia 2008;32(2):578-583.

Murakami A, Ariki J. Produção de codornas japonesas. Jaboticabal: Funep 1998. p.78.

Pedroso AA Café MB Leandro NSM, Stringhini $H$, Chaves LS Desenvolvimento embrionário e eclodibilidade de ovos de codornas armazenados por diferentes períodos e incubados em umidades e temperaturas distintas. Revista Brasileira de Zootecnia 2006;35(6):23442349.

Sarcinelli MF. Efeitos da temperatura de incubação e da idade da matriz no desenvolvimento in ovo, qualidade, desempenho e produção de ovos da progênie de codornas japonesas [dissertation]. Jaboticabal (SP): Universidade Estadual Paulista; 2012

SAS Institute. SAS proprietary software release 9.2. Cary; 2012.

Seker I, Kul S, Bayraktar M. Effects of storage period and egg weight of Japanese quail eggs on hatching results (short communication). Archiv Für Tierzucht, Dummerstorf 2005;48:518-526

Sgavioli S, Matos Júnior JB, Borges LL, Praes MFFM, Morita VS, Zanirato GL, Garcia RG, Boleli IC. Effects of ascorbic acid injection in incubated eggs submitted to heat stress on incubation parameters and chick quality. Brazilian Journal of Poultry Science 2015;17(2):181-190.

Tona K, Bamelis F, Ketelaere B, Bruggeman V, Moraes VMB, Buyse J, Onagbesan O, Decuypere E. Effects of egg storage time on spread of hatch, chick quality, and chick juvenile growth. Poultry Science 2003:82:736-741. 